\title{
Two Factors Secreted by the Goldfish Optic Nerve Induce Retinal Ganglion Cells to Regenerate Axons in Culture
}

\author{
Jason M. Schwalb, Nicholas M. Boulis, Miao-fen Gu, Jonathan Winickoff, Paul S. Jackson, Nina Irwin, and \\ Larry I. Benowitz \\ Department of Neurosurgery, Children's Hospital (Boston), Program in Neuroscience and Department of Surgery, \\ Harvard Medical School, Boston, Massachusetts 02115
}

\begin{abstract}
Unlike mammals, lower vertebrates can regenerate an injured optic nerve and other pathways of the CNS throughout life. We report here that in dissociated cell culture, goldfish retinal ganglion cells regenerate their axons in response to two factors derived from the sheath cells of the optic nerve. Axogenesis factor 1 (AF-1) is a small peptide (700-900 Da) that is inactivated by treatment with proteinase $K$ but heat stable. A second factor, AF-2, is a polypeptide of ca $12 \mathrm{kDa}$. In the absence of these factors, dissociated retinal cells remained viable in serum-free, defined media for at least a week but showed little outgrowth, as visualized using the vital dye 5,6-carboxyfluorescein diacetate (5,6-CFDA). The addition of AF- 1 induced up to $25 \%$ of cells in culture to extend processes $>75 \mu \mathrm{m}$ in length by $6 \mathrm{~d}$; AF-2 had a lesser but highly significant effect. To verify that neurite outgrowth was from retinal ganglion cells per se, we applied the lipophilic dye 4-Di-10-ASP to the optic tectum and allowed it to diffuse up the optic nerve for several days before culturing the retina. A far greater percentage of cells containing the dye showed axonal outgrowth than was observed from the overall cell population, indicating that ganglion cells are selective targets of the factors. The effects of AF-1 or AF-2 were not secondary to enhanced viability, since neither overall cell survival nor the number of retinal ganglion cells remaining in culture after $6 \mathrm{~d}$ was affected by the presence of the factors. The activity of AF-1 and AF-2 was not mimicked by several defined factors tested over a broad concentration range, for example, NGF, BDNF, NT-3, CNTF, taurine, retinoic acid, acidic or basic fibroblast growth factors. The concentration of AF-1 is considerably higher in CM than in optic nerve
\end{abstract}

\footnotetext{
Received Feb. 24, 1995; accepted Apr. 17, 1995.

This work was supported by a grant from the National Eye Institute (NIH EY 05690), with additional funding from the Boston Neurosurgical Foundation and the Howard Hughes Medical Institute (to J.M.S. and N.M.B. as Medical Student Research Fellows). We thank Drs. Paul Rosenberg, Scott Pomeroy, and David Zurakowski (Children's Hospital, HMS); Drs. Dong-feng Chen, Gerald Schneider, and Sonal Jhaveri (MIT); Drs. Guo-fu Hu (HMS), Hadi Zanjani (Université de Paris). Wilbert Boek (Univ. Utrecht, The Netherlands), and David Teplow (Brigham and Women's Hospital, HMS); Katherine Langworthy (Wellesley College) and Michael Belliveau (HMS), all of whom made valuable suggestions or participated in various phases of the study. We are grateful to Regeneron (Tarrytown, NY) for providing CNTF, BDNF, NT-3, and NT-4/5 and Dr. Patricia D'Amore (Children's Hospital, Harvard Medical School) for basic FGF. This article is dedicated to the memory of Roger W. Sperry, a pioneer in the biology of nerve regeneration, who was L.I.B.'s thesis advisor

Correspondence should be addressed to Larry I. Benowitz, Ph.D., Labs for Neuroscience Research in Neurosurgery, Children's Hospital, Enders 312, 300 Longwood Avenue, Boston, MA 02115.
}

Copyright (C) 1995 Society for Neuroscience $0270-6474 / 95 / 155514-12 \$ 05.00 / 0$ homogenates, suggesting that it is actively secreted; AF-2 has a similar concentration intra- and extracellularly. Insofar as AF-1 and AF-2 derive from cells of the optic nerve and act upon retinal ganglion cells, they are likely to be important in inducing optic nerve regeneration in vivo.

[Key words: trophic factors, regeneration, goldfish, cell culture, visual system, axogenesis]

In humans and other higher vertebrates, neurons of the CNS fail to regenerate axons that have been injured by ischemia, neoplasia, inflammation, or trauma. Thus, the functional losses that follow these insults are generally irreversible. Lower vertebrates, in contrast, are able to regenerate injured CNS pathways throughout life (Sperry, 1944, 1963). In the goldfish, 95\% of retinal ganglion cells survive injury to the optic nerve (Meyer et al., 1985) and go on to reestablish topographically organized, functional connections with the optic tectum and other target areas within 1-2 months (reviewed in Grafstein, 1986; Jacobson, 1991). During the course of axonal regeneration, retinal ganglion cells undergo a dramatic enlargement of the nucleolus, proliferation of free ribosomes, and increase in cell diameter (Murray and Grafstein, 1969; Murray and Forman, 1971). At the molecular level, there is a marked upregulation in the expression of certain cytoskeletal components (Burrell et al., 1978; Giulian et al., 1980; Heacock and Agranoff, 1982; Quitschke and Schechter, 1983; Glasgow et al., 1992, 1994), cell adhesion molecules (Bastmeyer et al., 1990; Blaugrund et al., 1990; Vielmetter et al., 1991; Battisti et al., 1992; Paschke et al., 1992), and proteins associated with the growth cone, particularly GAP-43 (Benowitz ct al., 1981, 1983; Heacock and Agranoff, 1982; Perrone-Bizzozero et al., 1987; Perry et al., 1987; LaBate and Skene, 1989; Wilmot et al., 1993). Some of the same molecular changes occur during optic nerve development and regeneration in other species (Skene and Willard, 1981a,b; Moya et al., 1988; Doster et al., 1991).

The glial environment that surrounds an axon strongly influences its capacity to regenerate after injury (Aguayo et al., 1991). In the goldfish, the glial sheath cells of the optic nerve provide an environment that is highly conducive to axonal outgrowth (Bastmeyer et al., 1991, 1993). In part, this may be attributed to the expression of certain cell surface and extracellular matrix proteins, including an L1-like cell adhesion molecule (Blaugrund et al., 1990; Bastmeyer et al., 1991, 1993; Vielmetter et al., 1991; Battisti et al., 1992), laminin (Hopkins et al., 1985), and chondroitin sulfate proteoglycans (Battisti et al., 1992). In addition, goldfish optic nerve glia express lower levels of growth-inhibiting proteins on their surfaces than do mammalian 
CNS oligodendrocytes (Caroni and Schwab, 1988; Schwab and Caroni, 1988; Bastmeyer et al., 1991; Sivron et al., 1994) and secrete soluble factors that promote axonal outgrowth from goldfish retinal explants (Mizrachi et al., 1986), embryonic mammalian neurons (Finklestein et al., 1987; Caday et al., 1989), and the mature rabbit retina (Schwartz et al., 1985). Among the macromolecules identified in media conditioned by the glia and macrophages of the optic nerve are apolipoprotein A (Harel et al., 1989), plasminogen activator (Salles et al., 1990), interleukin-2 (Eitan et al., 1992), a transglutaminase (Eitan and Schwartz, 1993), and platelet-derived growth factor (Eitan et al., 1992).

In prior studies, several factors have been shown to enhance neurite outgrowth in goldfish retinal explant cultures if the regenerative process had been initiated by a conditioning lesion 1-2 weeks prior to explanting (Landreth and Agranoff, 1976, 1979; Turner et al., 1981, 1982; Johnson and Turner, 1982; Yip and Grafstein, 1982; Hopkins et al., 1985; Schwartz et al., 1985; Ford-Holevinski et al., 1986; Mizrachi et al., 1986; Lima et al., 1989; Hall et al., 1990; Schmidt et al., 1991). However, these agents generally had little effect if the regenerative process had not already begun in vivo, suggesting that the factors required to initiate regeneration derive from a source that is absent from the explant cultures, for example, optic nerve glia, the circulatory system, or other brain tissue (Johnson and Turner, 1982).

To investigate the endogenous factors that induce optic nerve regeneration, we have developed dissociated retinal cultures enriched in ganglion cells that had not been primed to regenerate in vivo. Cultures were grown at low cell densities and maintained in serum-free, defined media in order to minimize indirect effects mediated through other cell types and to enable us to quantify neurite outgrowth objectively. Our results show that retinal ganglion cells extend axons in response to either of two factors secreted by optic nerve glial cells: a small protease-sensitive, heat-resistant molecule of $600-900 \mathrm{Da}$ and a heat- and protease-sensitive molecule of $8-15 \mathrm{kDa}$. The activity of these two molecules was not mimicked by a host of identified factors.

\section{Materials and Methods}

Conditioned media. Comet goldfish (3-4" in length, Mt. Parnell Fisheries, Ft. Loudon, PA) were anesthetized by chilling to $4^{\circ} \mathrm{C}$ and sacrificed by cervical transection. Optic nerves (ONs) and tracts were dissected free from the eyes and optic tectum under $2 \times$ magnification, then separated from the remaining bone and connective tissue under $12 \times$ magnification using a table-top dissecting microscope (Wild-Heerbrugg). Following established procedures (Schwartz et al., 1985; Finklestein et al., 1987) with slight modifications, we cut six ONs into 1$2 \mathrm{~mm}$ segments, incubated them in $3 \mathrm{ml}$ of HEPES-buffered Liebovitz's I -15 medium (GIRCO/BRI, Gaithershurg, MD) for $3-4 \mathrm{hr}$ at $37^{\circ} \mathrm{C}$ in a $5 \% \mathrm{CO}_{2}$ environment, and filter-sterilized the $\mathrm{CM}$ with a $0.2 \mu \mathrm{m}$ low protein-binding syringe filter (Acrodisc, Gelman Sciences, Ann Arbor, MI). CM was either aliquoted and stored at $-80^{\circ} \mathrm{C}$ immediately or stored at $4^{\circ} \mathrm{C}$ for $1-5 \mathrm{~d}$ before being fractionated or used in bioassays. Protein determinations (Bradford method, BSA standard; Bio-Rad, Richnond, CA) indicate that CM typically has a protein concentration of ca. $100 \mu \mathrm{g} / \mathrm{ml}$.

To investigate whether the expression of trophic factors changes after optic nerve injury, we anesthetized goldfish in $0.5 \mathrm{mg} / \mathrm{ml} \mathrm{3-aminoben-}$ zoic acid ethylester (Sigma Chemical Co., St. Louis, MO) and placed them in a Plexiglass holder which fixed the position of the head and allowed a constant flow of aerated tank water to flow through the mouth and gills. To expose the optic nerves, we made two incisions $3 \mathrm{~mm}$ apart in the superior rim of the orbit, retracted the bone flap, dissected away orbital soft tissue and adventitia, and crushed the optic nerves bilaterally 1-2 mm behind the eyes using curved 4" jeweler's forceps. Animals were eliminated if the nerve was transected or if there was significant bleeding.
Dissociated retinal cultures. To prepare retinal cultures (Landreth and Agranoff, 1976, 1979; Schwartz and Agranoff, 1981; Dowling et al., 1985), we dark-adapted goldfish for at least $30 \mathrm{~min}$, sacrificed the animals, removed the eyes, and rinsed these in sterile L-15, 70\% EtOH, and L-15 in quick succession. We removed the lens, cornea, and iris using iris scissors and, under $25 \times$ magnification, teased the retina from the sclera and pigment epithelium. The remainder of the culture preparation was carried out within a laminar flow hood. We incubated four retinas in $5 \mathrm{ml}$ of sterile digestion solution ( $100 \mathrm{U}$ of papain (Worthington) plus $2.5 \mathrm{mg}$ of L-cysteine (Sigma) in HEPES buffered L-15, $\mathrm{pH}$ 7.4 , filter-sterilized) for $45 \mathrm{~min}$ at room temperature, replaced the digestion solution with $5 \mathrm{ml}$ sterile L-15, and triturated the tissue five times gently with a Pasteur pipette (bore size ca. $1.2 \mathrm{~mm}$ ) to break the retina into small pieces. The solution was again replaced with $5 \mathrm{ml}$ sterile L-15 and triturated vigorously five times to separate retinas into fine fragments and remove photoreceptor cells. We repeated this procedure in fresh L-15 three to five more times, holding the pipette tip against the bottom of the tube. This resulted in a single cell suspension enriched in ganglion cells.

Twenty-four well tissue culture dishes (Costar, Cambridge, MA) were coated with poly-L-lysine (MW $>300,000$. Sigma). To each well, we added, in reverse sequence, $50 \mu 1$ of retinal cell suspension, the experimental or control sample (brought up to $150 \mu \mathrm{l}$ with L-15), and 200 $\mu \mathrm{l}$ of $2 \times$ Medium E, a serum-free, defined culture supplement developed by combining elements of several published protocols (Dichter, 1978; Bottenstein, 1983; Walicke et al., 1986; Aizenman and deVellis, 1987). Medium E contains $20 \mathrm{~nm}$ hydrocortisone, $1 \mathrm{~mm}$ kainurinate, $100 \mu \mathrm{m}$ putrescine, $20 \mathrm{nM}$ progesterone, $30 \mathrm{~nm}$ selenium, $0.3 \mathrm{nM} \mathrm{3,3}$ '5triiodo-L-thyronine, $50 \mu \mathrm{g} / \mathrm{ml}$ holo-transferrin, $150 \mathrm{U} / \mathrm{ml}$ catalase, 60 $\mathrm{U} / \mathrm{ml}$ superoxide dismutase, $1 \%$ bovine serum albumin (Type $\mathrm{V}$, with free fatty acids), $10 \mu \mathrm{g} / \mathrm{ml}$ gentamicin, $5 \mu \mathrm{g} / \mathrm{ml}$ insulin, and $15 \mathrm{~mm}$ HEPES (all reagents from Sigma), titrated to $\mathrm{pH} 7.4$ and filter-sterilized. To facilitate preparation and help ensure reproducibility, we prepared the first six constituents together at a $25 \times$ concentration and stored this at $-20^{\circ} \mathrm{C}$ in $0.5 \mathrm{ml}$ aliquots. Experiments were generally carried out in a blinded, randomized fashion so that the investigator was unaware of the experimental samples present in each well. Every experiment included at least four wells of a positive control sample (prcviously validated $\mathrm{CM}$ at a $10-15 \%$ concentration), at least four wells of a negative control sample ( $\mathrm{L}-15$ and Medium $\mathrm{E}$ alone), and three to eight wells of each experimental sample. Plates were incubated for 5-6 d in a dark humidified tank at room temperature before being evaluated. Most experiments were repeated with material from two to five separate preparations.

Identification of retinal ganglion cells. On fish anesthetized with 0.5 $\mathrm{mg} / \mathrm{ml} \mathrm{3-aminobenzoic} \mathrm{acid} \mathrm{ethylester,} \mathrm{we} \mathrm{made} \mathrm{a} \mathrm{series} \mathrm{of} \mathrm{scalpel} \mathrm{in-}$ cisions above the optic tectum, retracted the bone flap, and placed several crystals of the lipophilic dye, 4-(4-didecylaminostyryl)- $N$-methylpyridinium iodide (4-Di-10-ASP; Molecular Probes, Inc,, Portland, OR) directly on the optic tecta. The bone flap was replaced and sealed with Aron Alpha (Ted Pella, Inc.). Fish were allowed to survive for 5-9 d to allow the dye to be transported back to the ganglion cells. We then sacrificed the animals (after chilling to $4^{\circ} \mathrm{C}$ ), dissected the retinas, dissociated the cells, and cultured these in the presence of either $10 \% \mathrm{CM}$ or control media. After $6 \mathrm{~d}$ in culture, we quantified neurite outgrowth in 4-Di-10-ASP labeled cells using fluorescent microscopy. In addition to providing data about neurite outgrowth from ganglion cells per se, these studies allowed us to define criteria for identifying RGCs in the standard heterogeneous cultures used in the rest of the study.

Neurite outgrowth assay: standard heterogeneous cultures. After $6 \mathrm{~d}$ in culture, the medium was removed and cells were incubated with 0.1 $\mathrm{mg} / \mathrm{ml} \mathrm{5,6-carboxyfluorescein} \mathrm{diacetate} \mathrm{(CFDA,} \mathrm{Sigma)} \mathrm{in} \mathrm{phosphate-}$ buffered saline (PBS) for $10 \mathrm{~min}$. CFDA is taken up and metabolized by living cells to yield a fluorescent product that is distributed throughout the entire cell, enabling us to assess cell viability and neurite outgrowth simultaneously. After replacing CFDA with PBS, we examined the cultures at $200 \times$ magnification under fluorescent illumination (Nikon AF-BS inverted microscope, green barrier filter), recording the number of viable cells in a strip one well radius long (16 consecutive fields starting at the top of the well) along with the neurite outgrowth in cells that matched the morphological criteria for retinal ganglion cells (as established in the retrograde labeling experiments). Following the initial characterization of the system, we collapsed data bins to give a single measure of neurite outgrowth, ([number of cells with neurites $>$ 5 cell diameters $] \div$ [total number of viable cells] $) \times 100$. Data are 

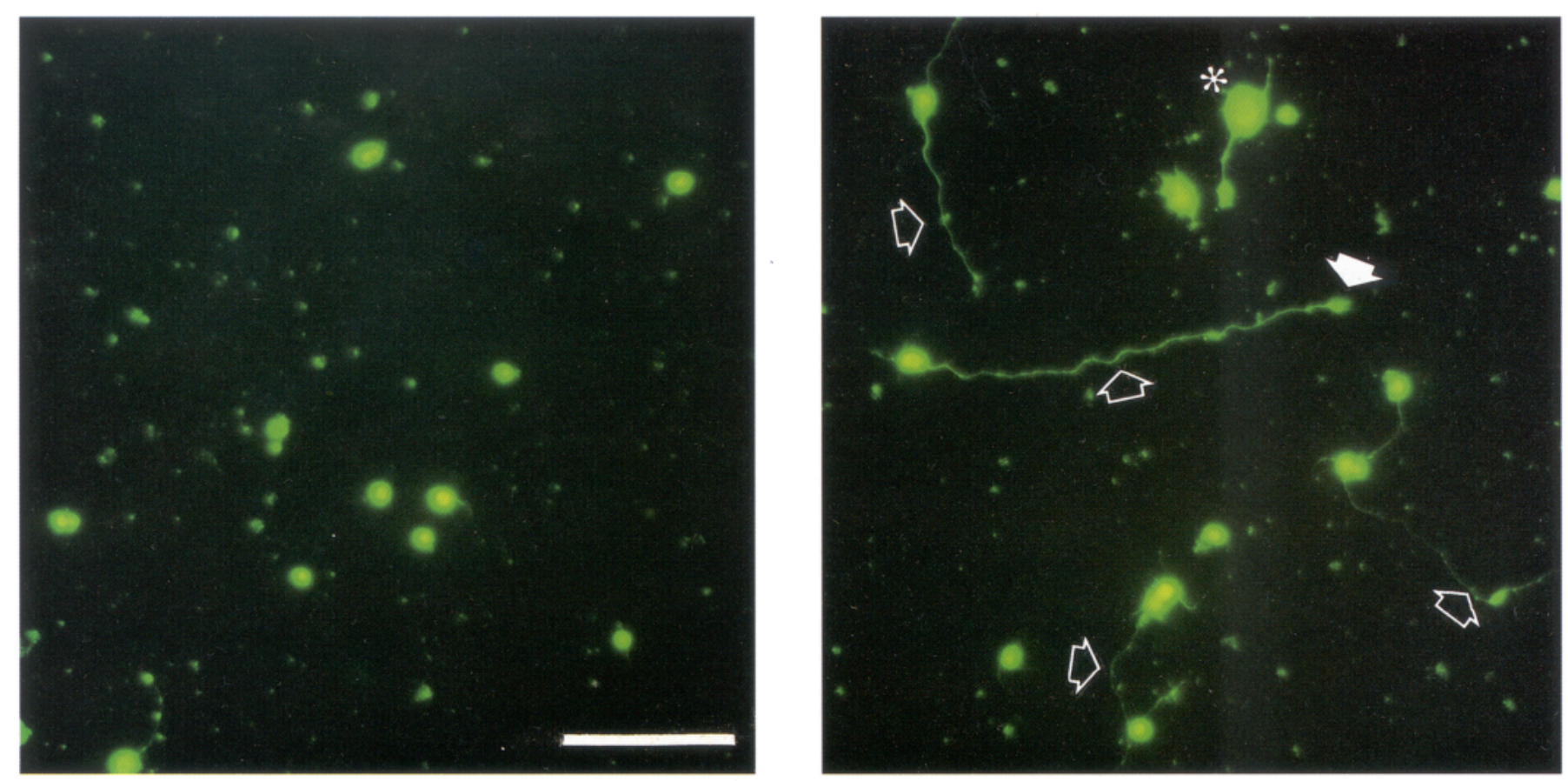

Figure 1. Response of dissociated retinal cells to factors secreted by the optic nerve. Left, Under baseline conditions, cells in culture remain viable for at least $6 \mathrm{~d}$ but show little outgrowth, as demonstrated using the vital dye 5,6-CFDA. Right, With the addition of CM containing factors secreted by the optic nerve, cells 10-17 $\mu \mathrm{m}$ across extend one or two long processes of a uniformly thin caliber (open arrows), which sometime terminate in a prominent growth cone (solid arrow). Larger, polygonal cells (asterisk) are not included when quantifying neurite outgrowth. Scale bar, $100 \mu \mathrm{m}$.

presented as the mean \pm standard error of 3-8 replicates. Where appropriate, data have been normalized by subtracting the growth in the negative controls and dividing by the net growth in the positive controls. Comparisons between conditions are based upon two-tailed $t$ tests.

Size fractionation. At various stages of the study, CM was passed through a $6 \mathrm{kDa}$ desalting column (Bio-Rad) or separated by centrifugal ultrafiltration using filters with molecular weight cutoffs of $1 \mathrm{kDa}$ (Filtron, Northborough, MA), 3, 10, or $100 \mathrm{kDa}$ (Amicon, Beverly, MA). After establishing the general size ranges of the active factors, material with a molecular weight $>3 \mathrm{kDa}$ was concentrated 10-100-fold using a Centriprep-3 filter (Amicon) and separated by high performance liquid chromatography (HPLC, Beckman Instruments) using a Biosep SecS3000 N-capped bonded silica column (Phenomenex, Torrance, CA). Low molecular weight material $(<1 \mathrm{kDa})$ was concentrated $10-15 \times$ by lyophilization and separated on a Biosep Sec S2000 column (Phenomenex). The elution profiles of both were monitored spectrophotometrically (at 280 or $215 \mathrm{~nm}$ ). Column fractions ( $1 \mathrm{ml}$ each) were screened in the bioassay irrespective of whether absorption peaks were seen.

Heat and protease treatment. Stability was evaluated by heating samples at $95^{\circ} \mathrm{C}$ for $15 \mathrm{~min}$. Sensitivity to proteases was determined by adding trypsin (Sigma) to a concentration of $1 \mathrm{mg} / \mathrm{ml}$ and then soybean trypsin inhibitor at $1.25 \mathrm{mg} / \mathrm{ml}$, either together with the trypsin or after a 1 or $2 \mathrm{hr}$ delay. The low molecular weight fraction of $\mathrm{CM}(<3 \mathrm{kDa})$ was exposed to two different samples of proteinase $\mathrm{K}$ (Boehringer Mannheim or Calbiochem; $50 \mu \mathrm{g} / \mathrm{ml}, 56^{\circ} \mathrm{C}, 1 \mathrm{hr}$ ). Following incubation, low molecular weight factors were separated from the active proteases with a Centriprep-3 filter. Controls included heating samples without enzymes and incubating the enzyme by itself at $56^{\circ} \mathrm{C}$ for $1 \mathrm{hr}$, filtering, and then adding the filtrate to the $<3 \mathrm{kDa}$ fraction to verify that proteases were not generating autolytic fragments that affect cell growth.

Anion exchange chromatography. We carried out anion-exchange chromatography on diethylaminoethyl cellulose columns (DE-52, Whatman, Hillsboro, OR) at either $\mathrm{pH} 8.4$ or $\mathrm{pH} 10$. DE-52 beads were preequilibrated with $25 \mathrm{~mm}$ HEPES at the appropriate $\mathrm{pH}$ and added to the high molecular weight fraction of $\mathrm{CM}$ at a ratio of $0.5 \mathrm{ml}$ hydrated beads: $10 \mathrm{ml}$ desalted $\mathrm{CM}$. After an overnight incubation $\left(4^{\circ} \mathrm{C}\right)$, we transferred the mixture to $5 \mathrm{~mm}$ I.D. Econo-columns (Bio-Rad) and eluted the bound proteins stepwise with $0.1,0.2,0.5$, and $1.0 \mathrm{M} \mathrm{NaCl}$ in $25 \mathrm{mM}$ HEPES ( $3 \mathrm{ml} / \mathrm{step})$.

Source of trophic factors. To investigate whether the trophic factors are actively secreted or simply released from cells of the optic nerve damaged in the dissection, we compared the activity of the high- and low-molecular weight fractions of CM and optic nerve cytosol. Cytosol was prepared by homogenizing 10 optic nerves in 25 mM HEPES, pH 7.4 , and centrifuging at $15,000 \times g$ for $10 \mathrm{~min}$. The soluble fraction was matched for protein concentration to whole CM using the Bio-Rad protein assay. Optic nerve cytosol and CM were separated into high and low molecular weight fractions with a Centriprep-3 filter and the fractions bioassayed. We also examined whether the active factors were specific to the optic nerve by comparing standard CM with media containing factors secreted by other goldfish tissues. The optic nerves required to prepare $3 \mathrm{ml}$ of $\mathrm{CM}$ were weighed prior to mincing. Equal masses of tissue from goldfish liver, gill, and skeletal muscle were used to prepare other conditioned media. To evaluate other brain tissue, we prepared conditioned media from six goldfish optic tecta; bioassays were carried out matching the protein concentration of optic tectum conditioned media to that of standard optic nerve conditioned media.

To evaluate the effects of molecules previously found to affect growth in retinal explant cultures, we tested taurine (at concentrations of $10^{-9}$ to $10^{-3} \mathrm{M}$; Sigma), retinoic acid $\left(10^{-9}\right.$ to $10^{-4} \mathrm{M}$; Sigma), NGF ( $\beta$ subunit, 1-100 nM; Collaborative Research, Bedford, MA), brain-derived neurotrophic factor (BDNF), neurotrophic factor 3 (NT-3), NT-45 , ciliary neuronotrophic factor (CNTF; previous four factors all from Regeneron, Tarrytown, NY, tested at $1-100 \mathrm{ng} / \mathrm{ml}$ ), acidic fibroblast growth factor (aFGF, R\&D Systems, Minneapolis, MN; $1-100 \mathrm{ng} / \mathrm{ml}$ ), and basic fibroblast growth factor (gift of Dr. Patricia D'Amore, 1-100 $\mathrm{ng} / \mathrm{ml}$ ) in the bioassay. Additional experiments were carried out to examine whether the response of RGCs to CM depended on the density of plating in culture. In addition to the standard cell density used throughout our studies, we plated cells at 1/3, 1/9, and 1/27 this density.

\section{Results}

Dissociated retinal cells respond to factors derived from the optic nerve. Six days after plating the dissociated retina in the presence of L-15 and medium E alone, cells remained viable but showed little neurite outgrowth, as demonstrated using the vital dye 5,6-CFDA (Fig. 1, left). Four percent of cells had neurites between 1-5 cell diameters in length and fewer than $1 \%$ had 
a.
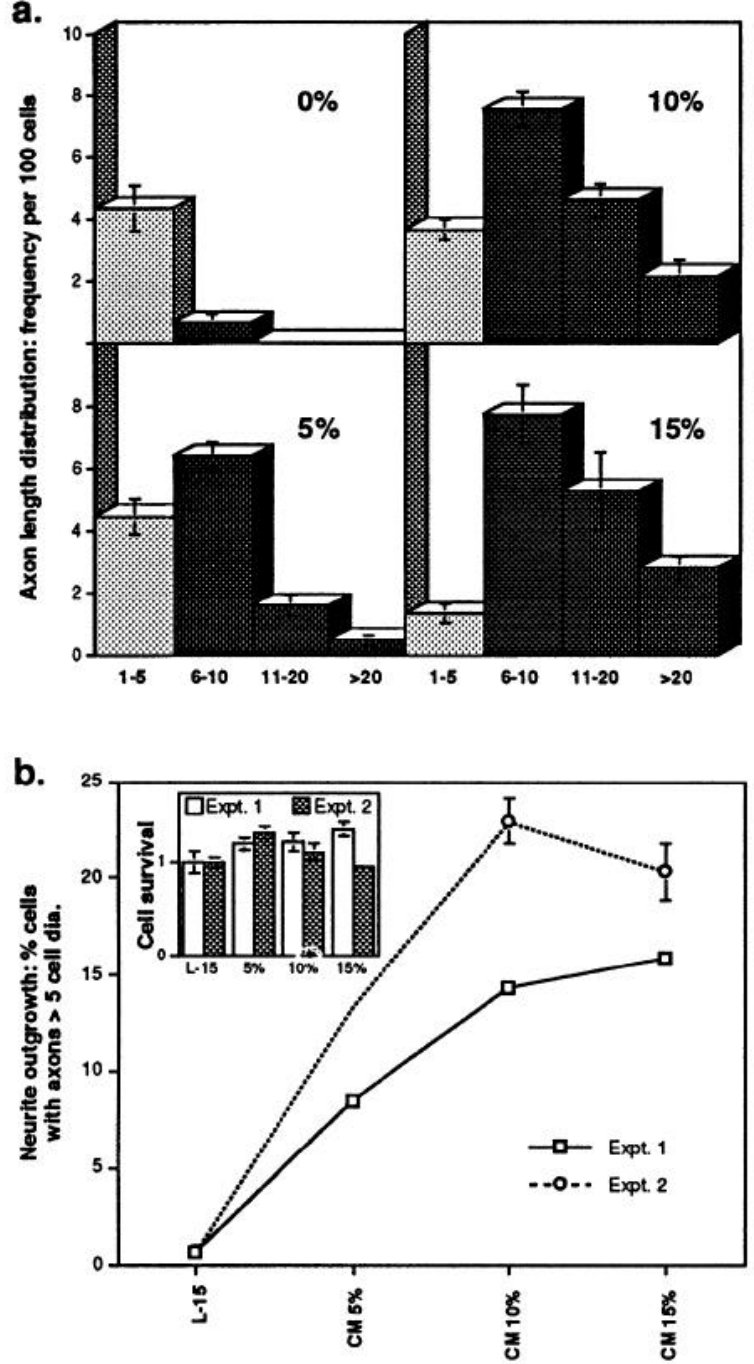

Figure 2. Quantitation of neurite outgrowth. $a$, Histograms of axon length distribution after $6 \mathrm{~d}$ in culture. Although outgrowth of short processes occurs spontaneously even under control conditions, increasing concentrations of $\mathrm{CM}$ markedly increase the number of cells extending processes $>5$ cell diameters in length (dark shading). Values represent averages of four wells for each $\mathrm{CM}$ concentration $\pm \mathrm{SE}$. $b$, Overall neurite outgrowth in response to increasing concentrations of CM: dose-response curves for two independent experiments. Data represent the percentage of cells with processes $>5$ cell diameters in length, a cutoff point selected based upon the histogram data in $(a)$. Maximal response is attained in response to $\mathrm{CM}$ at a $10-15 \%$ concentration (corresponding to a total protein concentration of ca. $10 \mu \mathrm{g} / \mathrm{ml}$ ). Error bars are not shown if less than $1 \%$. Inset, Cell survival as a function of $\mathrm{CM}$ concentration in two independent experiments $(5,6-$ CFDA labeled cells in 14 consecutive microscope fields averaged for four wells and normalized by L-15 control values).

processes longer than this (Fig. 2a). Counting a strip through 1 well radius allowed a sampling of 200-300 cells/well, corresponding to a density of about 70 cells $/ \mathrm{mm}^{2}$. Addition of media containing factors secreted by the optic nerve induced cells to extend long processes (Fig. 1, right). With $\mathrm{CM}$ present at a 5\% concentration, $7 \%$ of cells had neurites 5-10 cell diameters in length and $2 \%$ had even longer processes. With higher concentrations of CM (15\%), there were few cells left with axons in the 1-5 cell diameter range, while $7 \%$ had axons $>10$ cell diameters. On the basis of these axon length histograms, we subsequently report outgrowth as the percentage of cells with
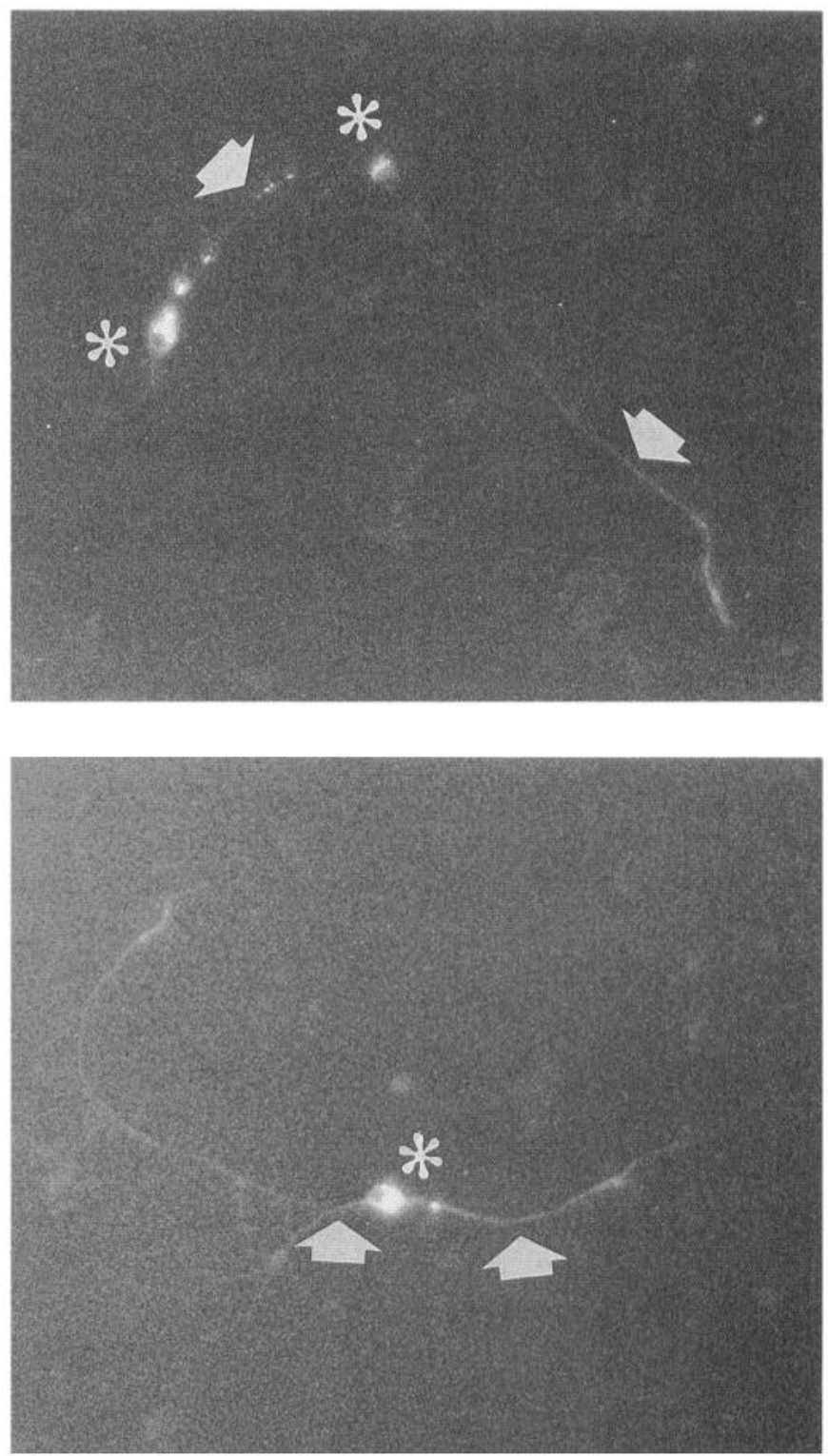

Figure 3. Neurite outgrowth from retinal ganglion cells. The lipophilic dye 4-Di-10-ASP was applied to the optic tectum $7 \mathrm{~d}$ prior to dissociating and culturing retinas. After $6 \mathrm{~d}$ in culture, retrogradely labeled ganglion cells extended one (top) or two (bottom) processes (arrows) in the presence of CM. Asterisks indicate somata.

axons $>5$ cell diameters, a cutoff point which discriminates responsive and nonresponsive groups well. Figure $2 b$ shows the dose-response curves of two experiments using different preparations of $\mathrm{CM}$ and retinas.

In both, the number of cells with axons $>5$ cell diameters in length increases continuously for CM concentrations up to $10 \%$, then levels off (outgrowth in response to $5 \% \mathrm{CM}$ vs $\mathrm{L}-15+$ Medium $\mathrm{E}$ alone, $p<0.001$ in each experiment; growth with $10 \% \mathrm{CM}$ vs $5 \% \mathrm{CM}, p<0.02$ for both; error bars not shown if less than $1 \%$ ). The difference in the number of cells showing outgrowth in the two experiments may reflect differences in the percentage of RGCs present in the two preparations.

The inset demonstrates that $\mathrm{CM}$ has little effect on cell viability. In both studies, the number of viable cells in 14 consecutive microscope fields (i.e., 1 well radius; four wells for each 

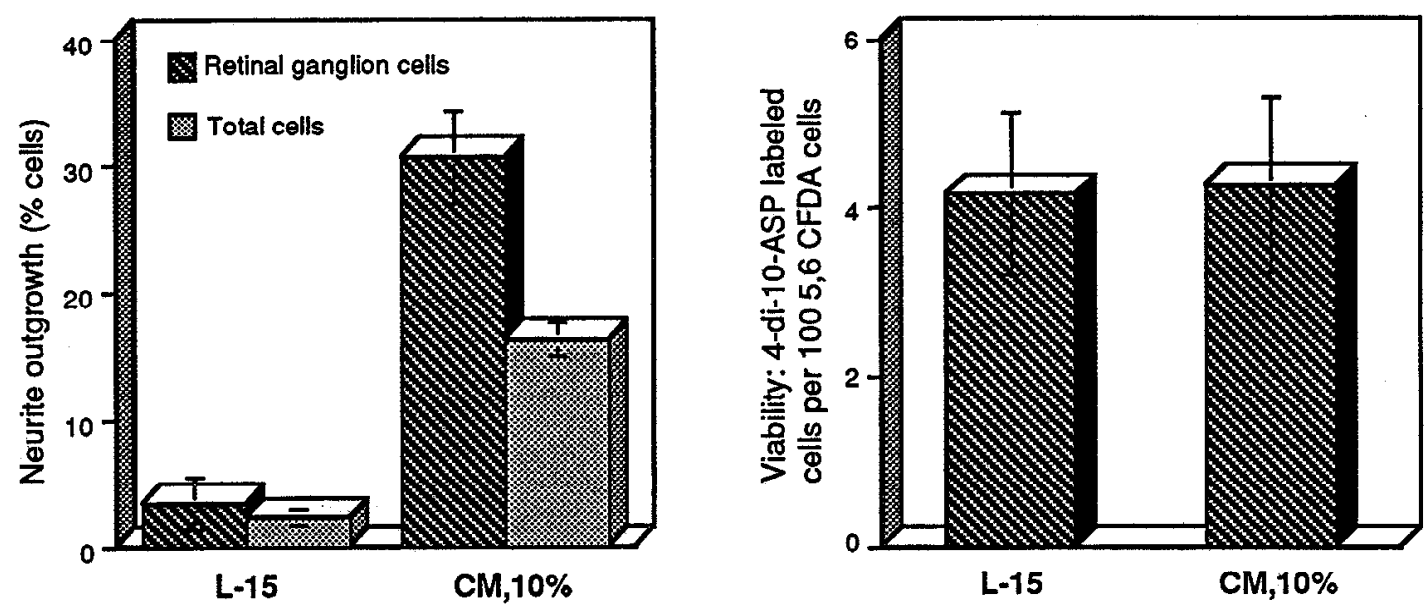

Figure 4. Retinal ganglion cells are stimulated selectively by factors secreted from the optic nerve. $a$, Under control conditions $(L-15+M e d i u m$ $E$ alone), retrogradely labeled RGCs showed little spontaneous outgrowth; in response to CM at a $10 \%$ concentration, over $30 \%$ of these cells extended axons $>5$ cell diameters in length, twice the percentage for the overall cell population in these experiments. $b$, The survival of RGCs is unaffected by CM. The number of retrogradely labeled cells in culture, divided by the total number of viable cells, was 4-5\% irrespective of the presence or absence of CM (data in $a$ and $b$ are pooled from two separate experiments, each containing four wells for each condition).

condition), normalized by the number of viable cells in the negative control (to account for differences in plating densities in the two experiments) showed little change with increasing CM concentration. Although viability appeared to be elevated in response to $15 \% \mathrm{CM}$ in one experiment, this failed to achieve statistical significance (15\% CM vs L-15, $p=0.21$ ) and was not scen in the sccond study.

Identification of retinal ganglion cells. Retinal ganglion cells were identified by applying the lipophilic dye 4-Di-10-ASP to a small region of the optic tectum and allowing the dye to diffuse along the optic nerve for 5-9 d before plating cells. After $6 \mathrm{~d}$ in culture, $4-5 \%$ of the cells were labeled. Labeled cells were ellipsoid, measuring 8-10 $\times 16-18 \mu \mathrm{m}$, similar to the dimensions of RGCs reported previously (Schwartz and Agranoff,

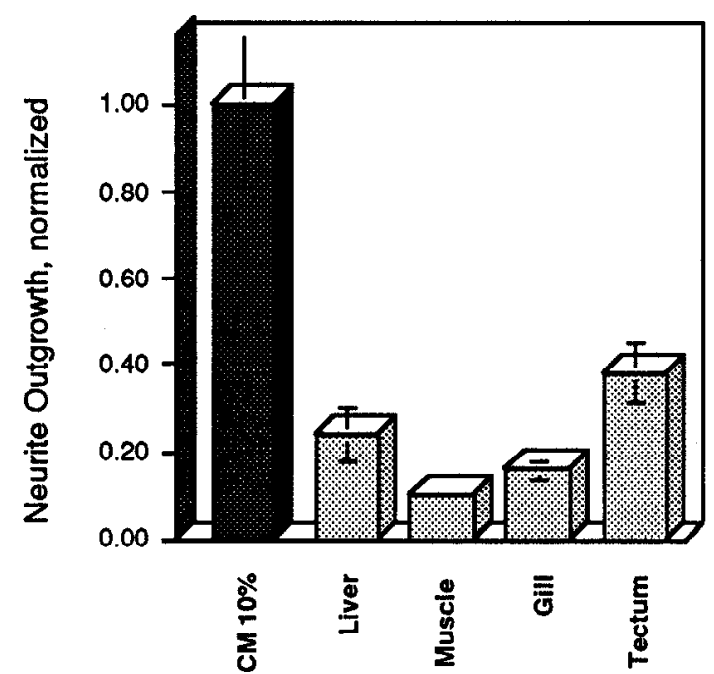

Figure 5. Specificity of neurite-promoting activity to media conditioned by the optic nerve. When media conditioned by equal masses of optic nerve, liver, muscle, and gill were tested at $10 \%$ concentrations, extensive neurite outgrowth was stimulated only by factors secreted by the optic nerve; media conditioned by the goldfish optic tectum, when added to cultures at the same protein concentration as CM from optic nerves, induced onc-third the level of neurite outgrowth as optic nerve CM.
1981). Identified RGCs showed little spontaneous outgrowth in the presence of L-15 and Medium E alone (see Fig. $4 a$ ), but showed more than twice the level of neurite outgrowth observed in the overall cell population in response to $10 \% \mathrm{CM}$ (see Fig. $4 a$; outgrowth in RGCs vs total cells, $p<0.005$ ). RGCs generally extended one or two long, thin processes (Fig. 3). CM had no effect on the viability of retrogradely labeled cells (Fig. $4 b$ ). Thus, the effect of CM on RGCs is not a consequence of enhancing the survival of this cell type. Since we know from retrograde labeling that approximately one-third of neurons identified as RGCs grow in response to CM, and since $15-25 \%$ of the total cell population extends neurites $>5$ cell diameters, it follows that RGCs probably constitute $45-75 \%$ of the mixed cultures.

Tissue specificity of conditioned media. Unlike media condilioned by the goldfish optic nerve, media conditioned by an equal mass of goldfish skeletal muscle, gill, or liver showed little neurite-promoting activity (Fig. 5; all samples differ from optic nerve CM at $p<0.01$ ). Media conditioned by the optic tectum, when matched for protein concentration to the optic nerve $\mathrm{CM}$ (i.e., ca. $10 \mu \mathrm{g}$ protein $/ \mathrm{ml}$ ), showed about one-third the activity of the optic nerve conditioned media (Fig. 5).

Optic nerve CM contains two trophic factors. After passing $\mathrm{CM}$ through a size-exclusion column with a molecular weight cutoff of $6 \mathrm{kDa}$ (Bio-Rad), neurite-promoting activity was found in both the high molecular weight fractions (containing most of the protein, as assessed by spectroscopy at O.D.280) and in lowmolecular weight fractions (assessed by measuring conductivity; data not shown). To examine whether the activity of these fractions changed after injury to the optic nerve, we prepared $\mathrm{CM}$ from optic nerves dissected either from normal goldfish or from animals 3 or $7 \mathrm{~d}$ after bilateral optic nerve crush, and then used the sizing column to separate samples into fractions $<6 \mathrm{kDa}$ and $>6 \mathrm{kDa}$. CM obtained from either intact or injured optic nerves yielded both high- and low molecular weight neurite-promoting factors (Fig. 6a; all samples show higher growth than the L-15 control at a level of $p<0.002$ ). The data in Figure $6 a$ indicate that most of the activity in unfractionated CM can be attributed to the smaller factor. Upon fractionation, $\mathrm{CM}$ from the optic 
a.
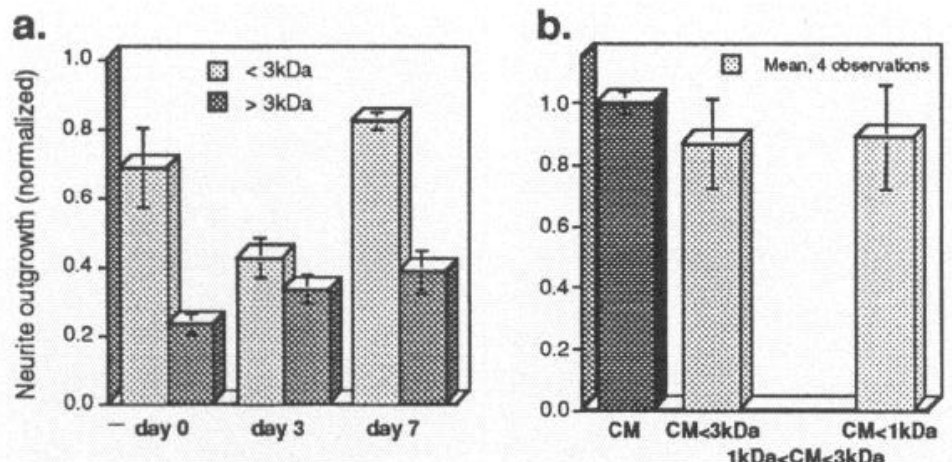

C.
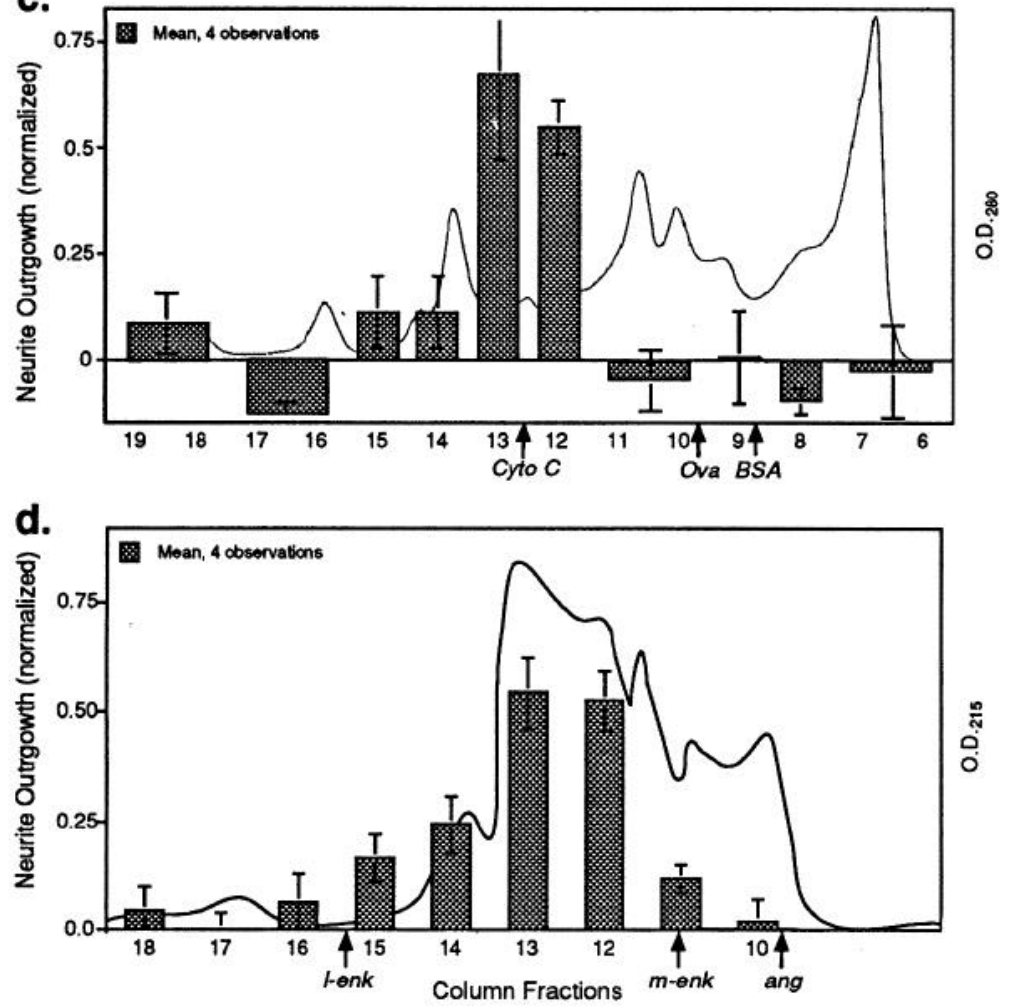

Figure 6. $\mathrm{CM}$ contains two distinct neurite-promoting factors. $a, \mathrm{CM}$, obtained from previously intact optic nerves (day 0) or from optic nerves which had been injured 3 or $7 \mathrm{~d}$ previously, was separated into high and low molecular weight fractions by sizeexclusion $(6 \mathrm{kDa}$ molecular weight cutoff). In all cases, both low (light shading) and high (dark shading) molecular weight fractions contained considerable neurite-promoting activity. $b$, High levels of neurite-promoting activity remained in $\mathrm{CM}$ after ultrafiltration with a molecular weight cutoff of $1 \mathrm{kDa} . c$, Chromatogram and activity profile of the high molecular weight fraction of $\mathrm{CM}$ after separation by size-exclusion HPLC (optical density, O.D., read at $280 \mathrm{~nm}$ ). Arrows indicate the retention times of the molecular weight calibration standards ( $B S A$, bovine serum albumin; Ova, ovalbumin; Cyto $C$, cytochrome C). Only fractions 12 and 13 contained significant neurite-promoting activity. $d$, HPLC chromatogram and activity profile of the low molecular weight fraction $(<1 \mathrm{kDa})$ of $\mathrm{CM}(\mathrm{OD}$ read at $215 \mathrm{~nm})$. Molecular weight standards include leu-enkephalin ( $l$ $e n k)$, met-enkephalin (m-enk), and angiotensin (ang). Activity was detected in fractions 12 and 13 , corresponding to molecular sizes of $600-900 \mathrm{Da}$. tectum was found to contain both high and low molecular weight trophic factors, each at about one-third the level found in optic nerve conditioned media (data not shown).

The smaller trophic factor is 600-900 Da in size. Further separation of CM using a Microsep filter (Filtron) with a $1 \mathrm{kDa}$ cutoff showed that essentially all of the activity $<3 \mathrm{kDa}$ also passed through the $1 \mathrm{kDa}$ filter (Fig. $6 b ;<1 \mathrm{kDa}$ fraction vs L-15 control, $p<0.01)$. We concentrated the $<1 \mathrm{kDa}$ fraction $15 \times$ by lyophilization and analyzed it by size-exclusion HPLC (Biosep Sec S-2000, Phenomenex). When tested in the bioassay, fractions 12 and 13 showed high levels of activity (Fig. 6d; difference in activity between fractions 12 and 13 vs L-15 significant at $p<0.02$ ). Based on the elution time of several small peptides [leu-enkephalin (leu, MW = 556), met-enkephalin (met, MW = 877), angiotensin I (angio, MW = 1297); all from Sigma], the active factor appears to have a size of 600-900 Da.

The larger trophic factor is $8-15 \mathrm{kDa}$ in size. Size-exclusion HPLC shows that the fraction of CM $>3 \mathrm{kDa}$ contains a complex mixture of polypeptides (Fig. $6 d$ ). Fractions were initially bioassayed in groups of 2 (with each component present at $20 \%$ concentration relative to the starting material); if pooled frac- tions showed any activity, they were rescreened individually, or in pairs again if not. In both the initial and secondary screens, we observed high levels of activity in fractions 12 and 13 [Fig. $6 d$; fraction 12 vs L-15, $p=0.01$; fraction 13 vs L-15, $p=$ 0.053 ; all others not significant (NS)]. The active factor has a similar retention time as cytochrome $\mathrm{C}(12 \mathrm{kDa}$; Fig. $6 c)$, and we therefore estimate its size to be $8-15 \mathrm{kDa}$. In some experiments, we observed an additional peak of activity at 70-100 $\mathrm{kDa}$, but this has not been reproducible. This larger molecule may be unstable and degrade to form the 8-15 kDa factor, or it may be a multimeric complex that dissociates under certain conditions.

Both factors are polypeptides. Upon heating at $95^{\circ} \mathrm{C}$ for 15 min, unfractionated CM lost about half of its activity (Fig. 7a, tested at 5\% concentrations; difference NS). When examined in isolation (at a $20 \%$ concentration), the high molecular weight fraction lost most of its activity after heating (comparing the activity of $\mathrm{CM}>3 \mathrm{kDa}$ before and after heating, $p=0.006$ ). In contrast, the low molecular weight fraction showed only a small loss in activity when subjected to $95^{\circ} \mathrm{C}$ for $15 \mathrm{~min}$ (Fig. $7 \mathrm{c}$ ). In response to proteolytic enzymes, unfractionated $\mathrm{CM}$ at a $5 \%$ 

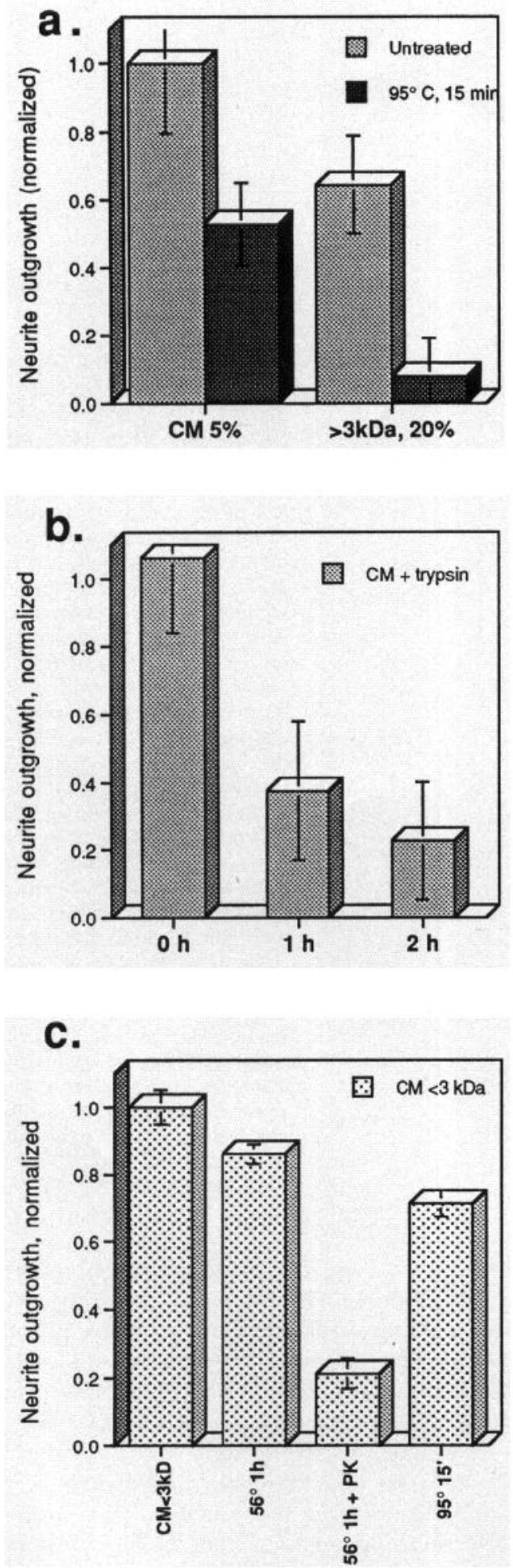

Figure 7. Heat and protease sensitivity of the two factors. $a$, When heated at $95^{\circ} \mathrm{C}$ for $15 \mathrm{~min}$ (dark shading), unfractionated CM lost half of its activity; the high molecular weight fraction, by itself, lost nearly all of its activity. $b$, Exposure to trypsin for 1 or $2 \mathrm{hr}$ diminished the activity of unfractionated $\mathrm{CM}$ by ca. $60 \%$; in the control $(0 \mathrm{hr})$, soybean trypsin inhibitor added at the same time as trypsin prevented the loss of activity. $c$, The low molecular weight factor by itself, incubated for $1 \mathrm{hr}$ at $56^{\circ} \mathrm{C}$ or for $15 \mathrm{~min}$ at $95^{\circ} \mathrm{C}$, lost only $20-25 \%$ of its activity (cf. $a$ and $b$ ). Incubation with proteinase $\mathrm{K}(P K)$ for $1 \mathrm{hr}$ at $56^{\circ} \mathrm{C}$ reduced its activity by $80 \%$. concentration lost about half of its activity after exposure to trypsin for 1 or $2 \mathrm{hr}$ (Fig. $7 \mathrm{~b}$ ). The low molecular weight factor, when tested in isolation, showed little trypsin sensitivity under these conditions, but was degraded when the trypsin concentration was dropped to $0.5 \mu \mathrm{g} / \mathrm{ml}$ (data not shown). When treated with proteinase $\mathrm{K}$ (Boehringer) for $1 \mathrm{hr}$ at $56^{\circ} \mathrm{C}$, the low molecular weight factor lost almost all of its activity (Fig. $7 c$; treatment at $56^{\circ} \mathrm{C}$ with and without proteinase $\mathrm{K}$ different at $p=$ $0.004)$. In a replicate experiment using another source of proteinase $\mathrm{K}$ (Calbiochem), 100\% of the activity was lost (not shown).

Charge and substrate binding. Ion-exchange chromatography was used to separate the larger factor further. On a DEAE anion-

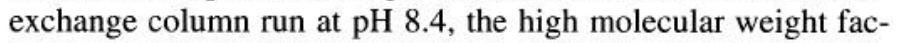
tor passed through the column without binding (Fig. 8a; activity in unbound fraction vs all others significant at $p<0.001$ ); on a similar column run at $\mathrm{pH} \mathrm{9.9,} \mathrm{the} \mathrm{active} \mathrm{factor} \mathrm{bound} \mathrm{to} \mathrm{the}$ column and eluted with $0.2 \mathrm{M} \mathrm{NaCl}$ (Fig. $8 b$; outgrowth with $0.2 \mathrm{M} \mathrm{NaCl}$ eluant vs L-15 significant at $p=0.012$ ).

Neither of the active factors acts as a substrate-bound growth factor. When polylysine-coated plates were incubated overnight with either the high or low molecular weight fraction of CM, either at full-strength or at a 1:10 dilution and then rinsed to remove unbound material, no neurite-promoting activity remained on the plates (Fig. 8c).

Intra- and extracellular concentration of the two factors. We investigated whether the active factors are likely to be secreted by comparing their activity in CM and in the high-speed supernatant fraction of optic nerve homogenates. Samples were used in the bioassay at concentrations of $10 \%$ and $20 \%$, adjusting the protein concentration of the optic nerve cytosol to match that of the CM. As shown in Figure 9, the low molecular weight factor is considerably more concentrated in CM than in the ON Cyto ( $p=0.002$ ), suggesting that the smaller molecule is actively secreted. The larger factor, on the other hand, is present at equal concentrations intra- and extracellularly.

Effect of cell density. To determine whether cell density affects the response of retinal ganglion cells to $\mathrm{CM}$, we plated retinas at either our standard density (ca. 70 cells $/ \mathrm{mm}^{2}$ ) or at increasingly lower densities. If CM targets another cell type that releases a secondary factor to influence RGCs, then as the density of this other cell type decreases, the concentration of anything it releases would decrease accordingly, leading to a diminished response of RGCs. However, at $1 / 3$ the standard cell density (i.e., ca. 25 cells $/ \mathrm{mm}^{2}$ ), retinal neurons actually had a slightly higher response to $10 \% \mathrm{CM}$ than at the standard density (NS; Fig. 10), and with another threefold dilution, outgrowth was only $30 \%$ lower than at the normal plating density ( $p=$ 0.18 , NS; Fig. 10). In contrast, CM at $1 / 9$ its maximally effective dose induces very little outgrowth (e.g., Fig. $2 b$ ). At 1/27 the standard cell plating density, outgrowth did decline $(p=0.05)$.

Activity of other molecules on dissociated retinal cultures. To investigate whether other factors mimic the activity found in $\mathrm{CM}$, we tested two small molecules that have been reported to modulate outgrowth in "primed" retinal cultures, along with several macromolecular growth factors. Taurine (Altshuler et al., 1993), at concentrations up to $10 \mathrm{~mm}$, had no effect at all (Fig. $11 a$ ), nor did retinoic acid (tested up to $100 \mu \mathrm{M}$; Fig. 11b). Preliminary experiments (J. Winickoff and N. Irwin) found no effects of NGF on dissociated retinal neurons at 5 and $50 \mathrm{~nm}$ and weak stimulation at $500 \mathrm{~nm}$. The results shown in Figure $11 c$ show an absence of NGF activity at $100 \mathrm{~nm}, 20$ times the 


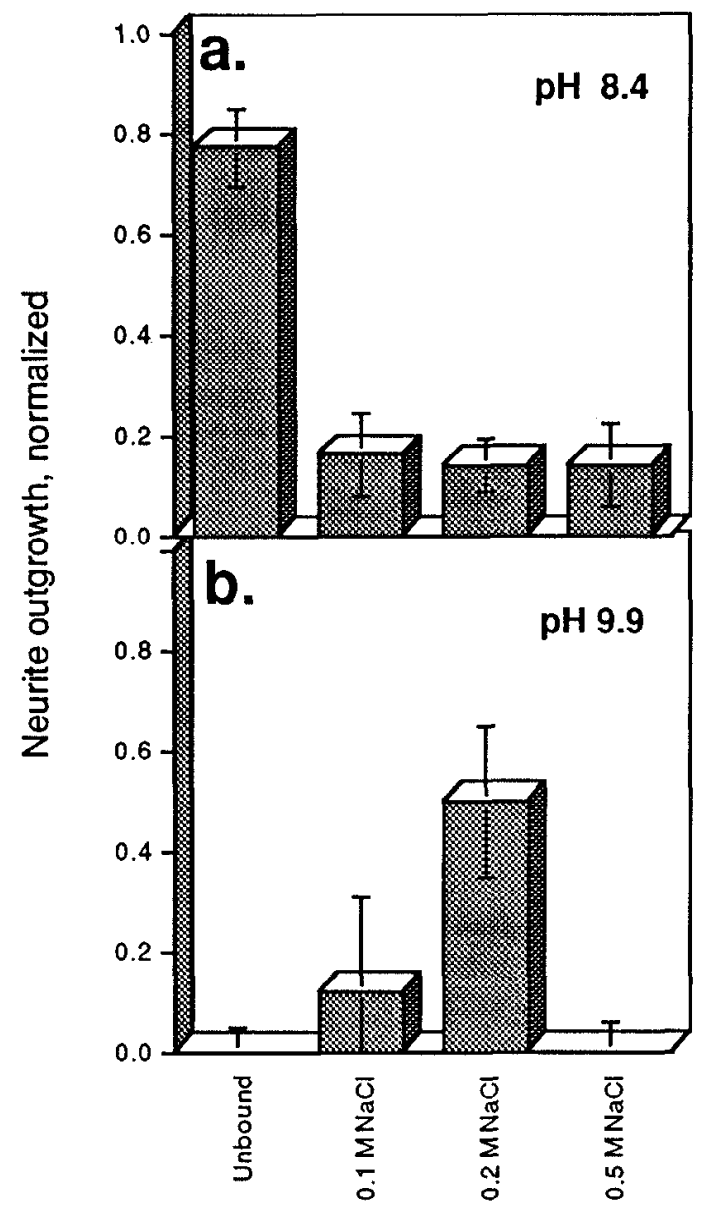

DEAE Column fractions

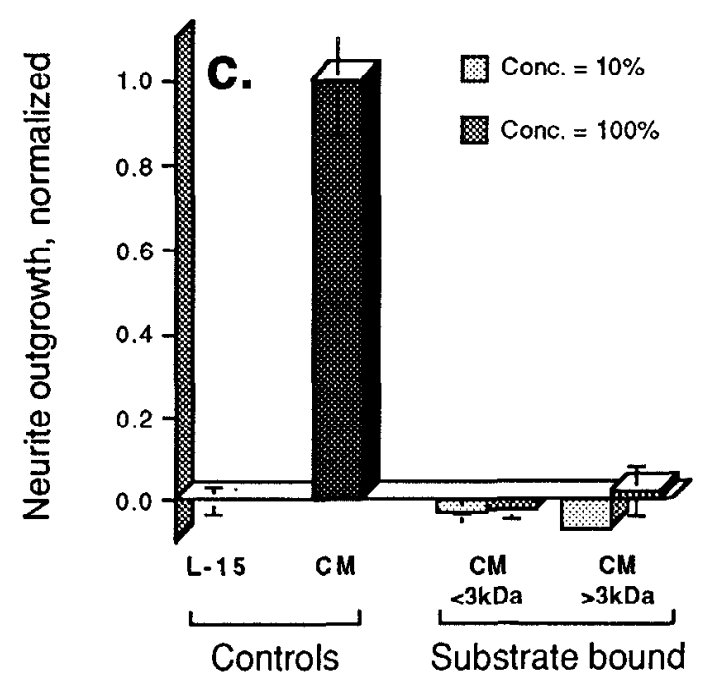

Figure 8. Additional properties of the two trophic factors. $a$ and $b$, Separation of the high molecular weight fraction of CM $(>3 \mathrm{kDa})$ by DEAE-anion-exchange chromatography. At $\mathrm{pH} 8.4$, neurite-promoting activity was recovered in the unbound fraction $(a)$, whereas at $\mathrm{pH} 10$, the active factor bound to the column and eluted with $0.2 \mathrm{M} \mathrm{NaCl}(b)$. $c$, Ncither component of CM acts as a substrate-bound trophic factor. $\mathrm{CM}$ was separated into high and low molecular weight fractions by ultrafiltration ( $3 \mathrm{kDa}$ cutoff); polylysine-coated wells were incubated with either fraction at a $10 \%$ concentration (light gray shading) or at full strength (medium gray) overnight, then rinsed mildly with L-15 medium.

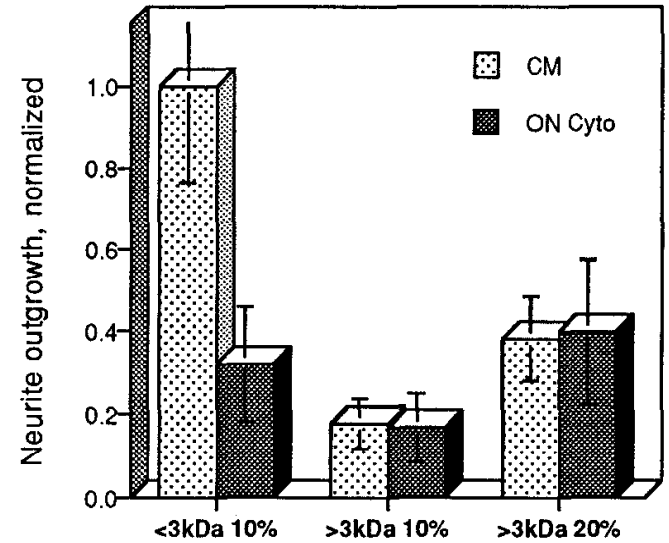

Figure 9. Neurite-promoting activity in conditioned media versus optic nerve cytosol. A high-speed supernatant of goldfish optic nerves was separated into high and low molecular weight fractions by ultrafiltration and tested in the bioassay at the same protein concentrations as optic nerve conditioned media. At equivalent total protein concentrations, the low molecular weight factor in $\mathrm{CM}(<3 \mathrm{kDa}$, light shading) showed significantly more neurite-promoting activity than the $<3 \mathrm{kDa}$ fraction of the optic nerve cytosol (dark shading); in contrast, the high molecular weight fractions of optic nerve CM and the high-speed supernatant showed similar levels of activity when tested at either $10 \%$ (ca. $10 \mu \mathrm{g} /$ $\mathrm{ml}$ each) or $20 \%$ (ca. $20 \mu \mathrm{g} / \mathrm{ml}$ each).

dosage that enhances axonal outgrowth in primed goldfish retinal explant cultures (Turner et al., 1982). Other neurotrophins likewise failed to induce outgrowth over a wide range of concentrations: BDNF, NT-3, and NT-4/5 (all gifts of Regeneron) were tested between $10 \mathrm{pg} / \mathrm{ml}$ and $100 \mathrm{ng} / \mathrm{ml}$ and all failed to elicit any axonal outgrowth (Fig. 11c; only results from the highest concentrations tested are shown). Non-neurotrophin growth factors that were tested between 1 and $100 \mathrm{ng} / \mathrm{ml}$ included acidic and basic fibroblast growth factors and ciliary neurotrophic factor. These likewise had no effect (only the results from concentrations of $100 \mathrm{ng} / \mathrm{ml}$ are shown in Fig. 11d).

\section{Discussion}

Regeneration of the optic nerve in lower vertebrates has been a classic model for studying the development and plasticity of

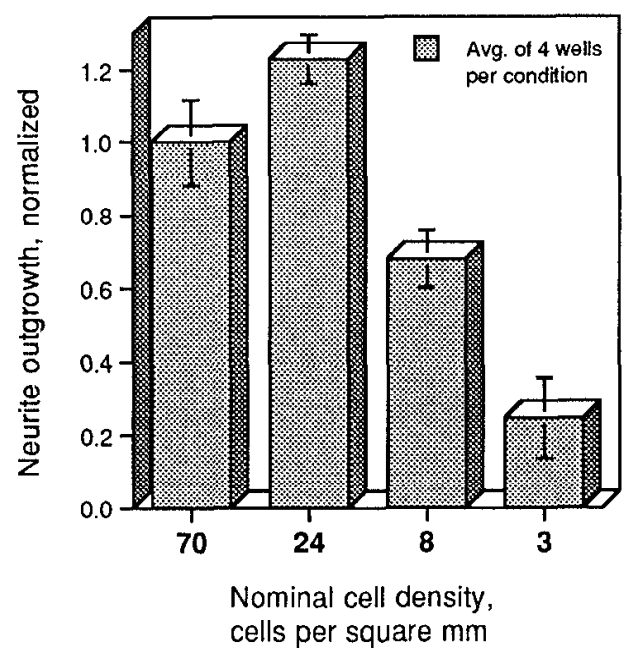

Figure 10. Effects of cell density on neurite outgrowth. Neurite outgrowth in response to $10 \% \mathrm{CM}$ showed no significant change when dissocialed retinal cultures were plated at $1 / 3$ or $1 / 9$ lhe standard density (e.g., ca. 24 or 8 cells $/ \mathrm{mm}^{2}$ ). At $1 / 27$ the standard density, however, outgrowth diminished significantly. 
Figure 11. Specificity of neurite-promoting effects to factors in optic nerve CM. $a$ and $b$, Retinoic acid and taurine had no effects on neurite outgrowth from dissociated goldfish retinal cultures when tested at the indicated concentrations. $c$, The neurotrophins NGF, BDNF, NT-3, and NT-4/5 all failed to promote neurite outgrowth when tested at concentrations between $10 \mathrm{pg} / \mathrm{ml}$ and $100 \mathrm{ng} / \mathrm{ml}$ (only the highest concentrations are shown). $d$, The trophic factors CNTF, acidic FGF and basic FGF likewise failed to induce neurite outgrowth when tested at concentrations between 1 and $100 \mathrm{ng} / \mathrm{ml}$ (only the highest concentrations are shown).

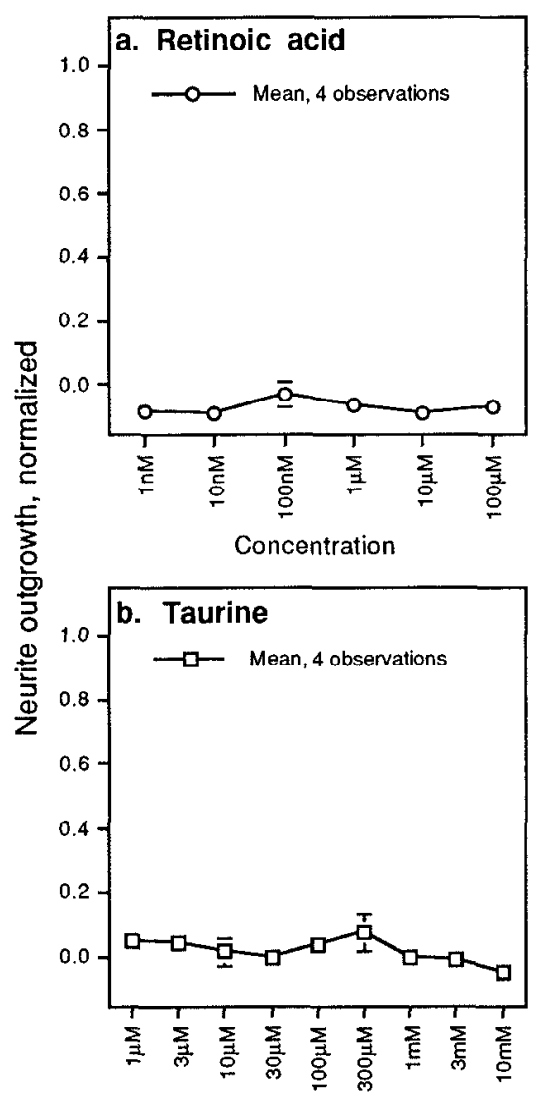

c. Neurotrophins

[100 ng/ml]
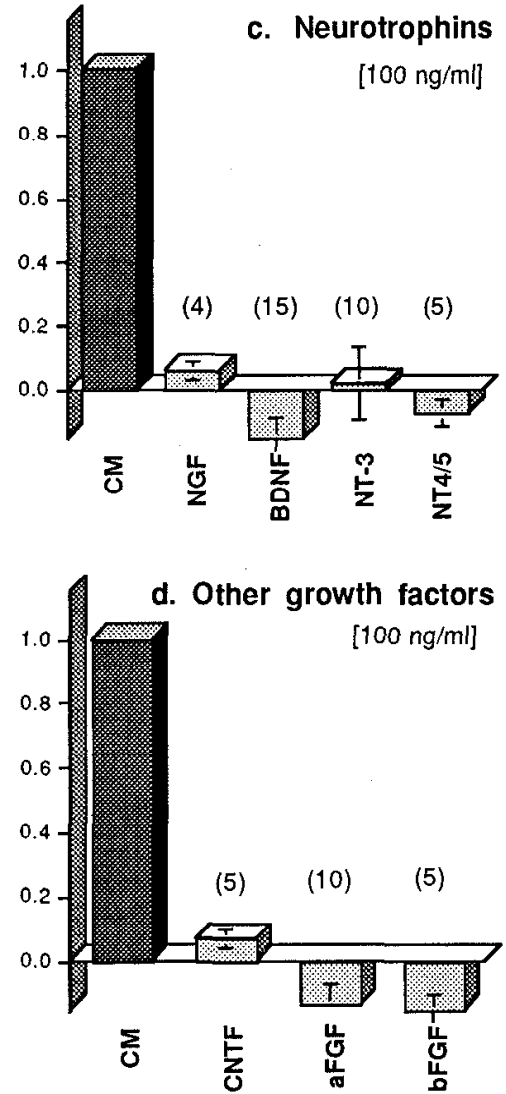

highly organized pathways in the CNS (Grafstein, 1986; Jacobson, 1991). To characterize the nature and source of the factors responsible for the induction of optic nerve regeneration, we developed a dissociated cell culture model of the goldfish retina grown in serum-free, defined media. Under these conditions, two factors that are secreted from the glial cells of the optic nerve induced retinal ganglion cells to extend lengthy, axon-like processes. One of these factors, tentatively named axogenesis factor 1 (AF-1), is a heat-stable, protease-sensitive molecule with a size of $600-900 \mathrm{Da}$; the second, $\mathrm{AF}-2$, is a heat-labile protein of with an estimated size of 8-15 kDa.

The goldfish optic nerve consists of several cell types, including oligodendroglia, astrocytes, macrophages, microglia, and epithelial cells (Battisti et al., 1992). The trophic factors could be secreted from any of these or, alternatively, they might only be released from the cytoplasm of cells that are injured by our dissections or that lyse in culture. To investigate this question, we compared the concentration of the two factors in conditioned media and optic nerve homogenates. If one assumes as a worst case scenario that most proteins appear in the CM as a consequence of cell lysis, then any protein that is present in equal concentrations intra- and extracellularly may not have been secreted actively, though it could still be of physiological significance when a nerve is injured. AF-1 was found to be present in significantly higher concentrations in CM than in optic nerve cytosol, indicating that it is probably secreted. AF-2, on the other hand, was present at similar concentrations intra- and extracellularly. Further evidence that AF-1 and AF-2 are produced by the glial sheath cells of the optic nerve comes from preliminary studies on media conditioned by dissociated longterm cultures of glial cells from the goldfish optic nerve (in collaboration with Drs. C. Stürmer and M. Bastmeyer, Univ. Konstanz, Germany). These studies indicate that media containing factors secreted from dissociated goldfish optic nerve glia contains high levels of a trophic factor $<3 \mathrm{kDa}$ and lower levels of onc $>3 \mathrm{kDa}$.

AF-1 and AF-2 do not appear to coincide with any of the molecules previously identified in goldfish optic nerve conditioned media. Mizrachi et al. (1986) described a $10 \mathrm{kDa}$ protein in optic nerve CM which is adsorbed onto polylysine substrate and which binds to DEAE at neutral $\mathrm{pH}$. This protein enhanced neurite outgrowth in retinal explants which had begun to regenerate their axons in vivo, but did not induce outgrowth from unprimed retinas. AF-2, in addition to inducing outgrowth from unprimed retinal ganglion cells, is not adsorbed onto substrate (Fig. 8c) and does not bind to DEAE even at pH 8.4 (Fig. $8 a$ ). Other components of CM that likewise differ from the ones described here include apolipoprotein A, a $28 \mathrm{kDa}$ protein that binds to heparin sulfate proteoglycans and which may contribute to lipid transport (Harel et al., 1989); a 60-65 kDa plasminogen activator that may be involved in the proteolysis of the extracellular matrix, thereby allowing growing axons to advance (Salles et al., 1990); a $28 \mathrm{kDa}$ protein resembling interleukin-2 (IL2; Eitan et al., 1992); a transglutaminase that may contribute to the dimerization of IL-2 and render it toxic to oligodendrocytes (Eitan and Schwartz, 1993); platelet-derived growth factor (Eitan et al., 1992); an acidic $26 \mathrm{kDa}$ protein that binds to polylysine substrate and induces axonal outgrowth from embryonic mammalian neurons (Caday et al., 1989); and laminin, a $10^{3} \mathrm{kDa}$ glycoprotein that is a major constituent of the extracellular matrix (Hopkins et al., 1985; Reichardt and Tomaselli, 1991; Battisti et al., 1992). Giulian and co-workers (Giulian and Young, 
1986; Giulian et al., 1986) described polypeptides of 3, 6, 9, and $125 \mathrm{kDa}$ that are secreted by the tectum after optic nerve injury and which contribute to the proliferation of particular macroglial populations of the nerve. Finally, a group of glycoproteins with molecular weights $\geq 37 \mathrm{kDa}$ (ependymins or X-GPs), which are secreted by cells of the choroid plexus and subependymal layer (Shashoua, 1985; Thormodsson et al., 1992), promote axonal outgrowth in primed explants (Schmidt et al., 1991). The fact that molecules matching these properties were not found to be active in our system suggests either that (1) their effects upon RGCs are too subtle to detect in our assay, (2) they may only work on RGCs which had been primed first in vivo, or (3) their primary effects are upon another cell type which acts upon RGCs secondarily.

The activity of AF-1 and AF-2 was not mimicked by several macromolecular trophic factors that we tested. NGF activity has been demonstrated in the goldfish brain (Benowitz and Greene, 1979). At low concentrations (i.e., $5 \mathrm{ng} / \mathrm{ml}$ ), the $\beta$-subunit of mammalian NGF augments neurite outgrowth from goldfish retinal explants which had been primed to grow in vivo (Turner et a1., 1982), and antibodies to NGF suppress outgrowth from primed retinal explants maintained in the presence of serum (Turner et al., 1982). However, NGF does not stimulate outgrowth from unprimed retinal explants (Turner et al., 1982), and does not affect the rate of axonal outgrowth in vivo (Yip and Grafstein, 1982). These results suggest that NGF may play a modulatory role in the regeneration of the goldfish optic nerve, perhaps by stimulating other cells to release factors that in turn act upon neurons. However, our studies and others indicate that it does not induce axonal outgrowth from retinal ganglion cells directly. Regarding other members of the neurotrophin family, the receptor for BDNF (i.e., $t r k \mathrm{~B}$ ) is abundant in retinal ganglion cells (Jelsma et al., 1993), and intraocular injections of BDNF attenuate cell death (Mey and Thanos, 1993) and promote local sprouting (Mansour-Robaey et al., 1994) after optic nerve injury in rats. Likewise, BDNF promotes the survival and outgrowth of rat retinal ganglion cells maintained in culture (Johnson et al., 1986). However, recombinant BDNF had no effect in our culture system, even at several times the concentration reported to be effective in mammalian retinal cultures (to help compensate for interspecies differences in molecular structure), nor did NT-3 nor NT-4/5. Nevertheless, it remains possible that factors such as BDNF are needed for cell survival but are already present in the cultures at sufficient concentrations that the addition of exogenous neurotrophin has no detectable effect. This is currently being investigated using antibodies to deplete specific neurotrophins. In addition to the neurotrophins, we found no effect from acidic FGF, which has been reported to enhance axonal outgrowth in mammalian mixed retinal cultures (Lipton et al., 1988), nor from basic FGF nor CNI't.

Taurine and retinoic acid were also examined in our cell culture system. Taurine contributes to the differentiation of rod cells (Altshuler et al., 1993) and augments neurite outgrowth from retinal explants, but only if they had been primed to regenerate in vivo (Lima et al., 1989). At concentrations between $1 \mu \mathrm{M}$ and $10 \mathrm{~mm}$, taurine failed to stimulate axonal outgrowth from retinal ganglion cells (Fig. 11a). Retinoic acid (RA), an important factor in cell differentiation, has been shown to enhance the expression of the intermediate filament proteins $\mathrm{ON}_{1}$ (gefiltin) and $\mathrm{ON}_{2}$ in goldfish retinal explants without affecting outgrowth per se (Hall et al., 1990). In agreement with these findings, the present study found no morphological effects of RA when tested between $10^{-9}$ to $10^{-4} \mathrm{M}$ (Fig. $11 \mathrm{~b}$ ). These findings demonstrate that the effects of AF-1 and AF-2 on RGCs are highly specific. One question that remains unresolved, however, is the relationship of the two factors to one another. AF-1 and AF-2 each induces neurite outgrowth in our assays, and their effects do not appear to be synergistic. Nevertheless, it is possible that in vivo they function in a complementary fashion. We also can not rule out the possibility that AF-1 is a degradation product of AF-2.

Since our cultures contain a variety of cell types, it is possible that $\mathrm{AF}-1$ and $\mathrm{AF}-2$ are not acting upon retinal ganglion cells directly, but upon another cell type as an intermediary. As observed previously (Schwartz and Agranoff, 1981), RGCs appear to be the dominant cell type in dissociatcd goldfish retinal cultures prepared by the method used here, and support cells are not abundant. Rather than trying to suppress the proliferation of support cells with metabolic blockers, we took the approach of reducing cell density to decrease the concentration of any secondary factors that might be released, while holding the concentration of CM constant. Since neurite outgrowth did not decline significantly over a ninefold decrease in cell density, it appears that the RGCs are responding to CM directly. At a cell density of ca. 3 cells $/ \mathrm{mm}^{2}$, however, outgrowth did decline significantly, possibly due to some factor required to maintain the responsiveness of neurons falling below a critical concentration. Along these lines, embryonic mammalian neurons in culture, when stimulated, release BDNF which functions in an paracrine manner to promote cell survival (Ghosh et al., 1994).

Comparative studies demonstrate a high degree of evolutionary conservation for molecules important for neural development and regeneration, for example, transcription factors, cytoskeletal elements, growth factors, cell surface recognition molecules, and vesicle sorting and fusion proteins. It is possible, then, that AF-1 and AF-2 have homologs that play a role in the development and regeneration of mammalian CNS pathways as well. If so, the human equivalents of these two factors, used in conjunction with agents to prevent secondary damage and to counter growth-inhibiting molecules on oligod endrocytes (Schnell et al., 1994), may have clinical significance.

\section{References}

Aguayo AJ, Rasminshy M, Bray GM, Carbonetto S, McKerracher L, Villegas-Perez MP Vidal-Sanz M, Carter DA (1991) Degeneration and regeneration of injured neurons in the nervous system of adult mammals. Philos Trans R Soc Lond [Biol] 331:337-343.

Aizenman Y, deVellis J (1987) Brain neurons develop in a serum and glial free environment: effect of transferrin, insulin, insulin-like growth factor I and thyroid hormone on neuronal survival growth and differentiation. Brain Res 406:32-42.

Altshuler D, Lo Turco JJ, Rush J, Cepko C (1993) Taurine promotes the differentiation of a vertebrate retinal cell type in vitro. Development 119:1317-1328

Barde YA, Edgar D, Thoenen H (1982) Purification of a new neurotrophic factor from mammalian brain. EMBO J 1:549-553.

Bastmeyer M, Schlosshauer B, Stuermer CA (1990) The spatiotemporal distribution of N-CAM in the retinotectal pathway of adult goldfish detected by the monoclonal antibody D3. Development 108: 299-311.

Bastmeyer M, Beckmann M, Schwab ME, Stuermer CAO (1991) Growth of regenerating goldfish axons is inhibited by rat oligodendrocytes and CNS myelin but not by goldfish optic nerve tract oligodendrocytelike cells and fish CNS myelin. J Neurosci 11:626-640.

Bastmeyer M, Bahr M, Stuermer CA (1993) Fish optic nerve oligodendrocytes support axonal regeneration of fish and mammalian retinal ganglion cells. Glia 8:1-11.

Battisti WP, Shinar Y, Schwartz M, Levitt P, Murray M (1992) TenIporal and spatial patterns of expression of laminin, chondroitin sul- 
phate proteoglycan and HNK-1 immunoreactivity during regeneration in the goldfish optic nerve. J Neurocytol 21:557-573.

Benowitz LI, Greene LA (1979) Nerve growth factor in the goldfish brain: biological assay studies using pheochromocytoma cells. Brain Res 162:164-168.

Benowitz LI, Lewis ER (1983) Increased transport of 44,000 to 49,000 dalton acidic proteins during regeneration of the goldfish optic nerve: a two-dimensional gel analysis. J Neurosci 3:2153-2163.

Benowitz LI, Shashoua VE, Yoon MG (1981) Specific changes in transported proteins during regeneration of the goldfish optic nerve. J Neurosci 1:300-307.

Blaugrund E, Bartsch U, Martini R, Schachner M, Schwartz M (1990) Immunological evidence that the neuronal adhesion molecule L1 is expressed in fish brain and optic nerve: possible association with optic nerve regeneration. Brain Res 530:239-244.

Bottenstein JE (1983) Defined media for dissociated neural cultures. In: Current methods in cellular neurobiology, Vol 4 (Barker JL, McKelvy JF, eds), pp 107-130. New York: Wiley.

Burrell HR, Dokas LA, Agranoff BW (1978) RNA metabolism in the goldfish retina during optic nerve regeneration. J Neurochem 31:289298.

Caday CG, Apostilides PJ, Benowitz LI, Perone-Bizzozero NI, Finklestein SP (1989) Partial purification and characterization of a neuritepromoting factor from the goldfish optic nerve. Mol Brain Res 5:4550.

Caroni P, Schwab ME (1988) Two membrane protein fractions from rat central myelin with inhibitory properties for neurite growth and fibroblast spreading. J Cell Biol 106:1281-1288.

Dichter MA (1978) Rat cortical neurons in cell culture: culture methods, cell morphology, electrophysiology, and synapse formation. Brain Res 149:279-293.

Doster KS, Lozano AM, Aguayo A, Willard MA (1991) Expression of growth-associated protein GAP-43 in adult rat retinal ganglion cells following axon injury. Neuron 6:635-647.

Dowling JE, Pak MW, Lasater EM (1985) White perch horizontal cells in culture: methods, morphology and process growth. Brain Res 360 : 331-338.

Eitan S, Schwartz M (1993) A transglutaminase that converts interleukin-2 into a factor cytotoxic to oligodendrocytes. Science $261: 106-$ 108.

Eitan S, Zisling R, Cohen A, Belkin M, Hirschberg DL, Lotan M, Schwartz M (1992) Identification of an interleukin 2-like substance as a factor cytotoxic to oligodendrocytes and associated with central nervous system regeneration. Proc Natl Acad Sci USA 89:54425446.

Finklestein SP, Benowitz LI, Olson AJ, Perrone-Bizzozero NI, Majocha RE, Apostolides PJ (1987) Conditioned media from the injured lower vertebrate CNS promote neurite outgrowth form mammalian brain neurons in vitro. Brain Res 413:267-274.

Ford-Holevinski TS, Hopkins JM, McCoy JP, Agranoff BW (1986) Laminin supports neurite outgrowth from the explants of axotomized adult retinal neurons. Brain Res 28:121-126.

Ghosh A, Carnahan J, Greenberg M (1994) Requirement for BDNF in activity-dependent survival of cortical neurons. Science 263:16181623 .

Giulian D, Young DG (1986) Brain peptides and glial growth. II. Identification of cells that secrete glia-promoting factors. J Cell Biol 102: $812-820$.

Giulian D, Des Ruisseaux H, Cowburn D (1980) Biosynthesis and intra-axonal transport of proteins during neuronal regeneration. J Biol Chem 255:6494-6501.

Giulian D, Allen RL, Baker TJ, Tomozawa Y (1986) Brain peptides and glial growth. I. Glia-promoting factors as regulators of gliogenesis in the developing and injured central nervous system. J Cell Biol 102:803-811.

Glasgow E, Druger RK, Levine EM, Fuchs C, Schechter N (1992) Plasticin, a novel type III neurofilament pro-tein from goldfish retina: increased expression during optic nerve regeneration. Neuron 9:373381.

Glasgow E, Druger RK, Fuchs C, Lane WS, Schechter N (1994) Molecular cloning of gefiltin (ON1): serial expression of two new neurofilament mRNAs during optic nerve regeneration. EMBO J 13:297305.

Grafstein B (1986) The retina as a regenerating organ. In: The retina: a model for cell biology studies, Pt 2 (Adler R, Farber DB, eds), pp 275-335. New York: Academic.

Hall CM, Else C, Schechter N (1990) Neuronal intermediate filament expression during neurite outgrowth from explanted goldfish retina: effect of retinoic acid. J Neurochem 55:1671-1682.

Harel A, Fainaru M, Shafer Z, Hernandez M, Cohen A, Schwartz M (1989) Optic nerve regeneration in adult fish and apolipoprotein A-I. J Neurochem 52:1218-1228.

Heacock AM, Agranoff B (1982) Protein synthesis and transport in the regenerating goldfish visual system. Neurochem Res 7:771 788 .

Hopkins JM, Ford-Holevinski TS, McCoy JP, Agranoff BW (1985) Laminin and optic nerve regeneration in the goldfish. J Neurosci 5:3030-3038.

Jacobson M (1991) Developmental neurobiology, 3d ed. New York: Plenum.

Jelsma TN, Friedman HH, Berkelaar M, Bray GM, Aguayo AJ (1993) Different forms of the neurotrophin receptor trkB mRNA predominate in rat retina and optic nerve. I Neurobiol 24:1207-1214.

Johnson J, Barde Y-A, Schwab M, Thoenen H (1986) BDNF supports survival of cultured rat retinal ganglion cells. J Neurosci 6:30313038 .

Johnson JE, Turner JE (1982) Growth from regenerating goldfish retinal cultures in the absence of serum or hormonal supplements: tissue extract effects. J Neurosci Res 8:315-329.

LaBate ME, Skene JHP (1989) Selective conservation of GAP-43 structure in vertebrate evolution. Neuron 3:299-310.

Landreth GE, Agranoff BW (1976) Explant culture of adult goldfish retina: effect of prior optic nerve crush. Brain Res 118:299-303.

Landreth GE, Agranoff BW (1979) Explant culture of adult goldfish retina: a model for the study of CNS regeneration. Brain Res 161: $39-53$.

Lima L, Matus P, Drujan B (1989) The interaction of substrate and taurine modulates the outgrowth from regenerating goldfish retinal explants. Int J Dev Neurosci 7:375-382.

Lipton SA, Wagner JA, Madison RD, D'Amore PA (1988) Acidic fibroblast growth factor enhances regeneration of processes by postnatal mammalian retinal ganglion cells in culture. Proc Natl Acad Sci USA 85:2388-2392.

Maisonpierre PC, Belluscio L, Squinto S, Ip NY, Furth ME, Lindsay RM, Yancopoulos GD (1990) Neurotrophin-3: a neurotrophic factor related to NGF and BDNF. Science 247:1446-1451.

Mansour-Robaey S, Clarke DB, Wang Y-C, Bray GM, Aguayo A (1994) Effects of ocular injury and administration of brain-derived neurotrophic factor on survival and regrowth of axotomized retinal ganglion cells. Proc Natl Acad Sci 91:1632-1636.

Mey J, Thanos S (1993) Intravitreal injections of neurotrophic factors support the survival of axotomized retinal ganglion cells in adult rats in vivo. Brain Res 602:304-317.

Meyer RL, Sakurai K, Schauwecker E (1985) Topography of regenerating optic fibers in goldfish traced with local wheat germ injections into retina: evidence for discontinuous microtopography in the retinotectal projection. J Comp Neurol 239:27-43.

Mizrachi Y, Rubinstein M, Kimhi Y, Schwartz M (1986) A neurotrophic factor derived from goldfish brain: characterication and purification. J Neurochem 46:1675-1682.

Moya KL, Benowitz LI, Jhaveri S, Schneider GE (1988) Changes in rapidly-transported proteins in developing hamster retinofugal axons. J Neurosci 8:4445-4454.

Murray M, Forman DS (1971) Fine structural changes in goldfish retinal ganglion cells during regeneration. Brain Res 32:287-298.

Murray M, Grafstein B (1969) Changes in the morphology and amino acid incorporation in regenerating goldfish optic neurons. Exp Neurol 23:544-560.

Paschke KA, Lottspeich F, Stuermer CAO (1992) Neurolin, a cell surface glycoprotein on growing retinal axons in the goldfish visual system is re-expressed during retinal axonal regeneration. J Cell Biol 117:863-875.

Perrone-Bizzozero NI, Benowitz LI (1987) Expression of a 48-kilodalton growth associated protein in the goldfish retina. J Neurochem $48: 644-652$.

Perry GW, Burmeister DW, Grafstein B (1987) Fast axonally transported proteins in regenerating goldfish optic axons. $J$ Neurosci 7:792-806.

Quitschke W, Schechter N (1983) Specific optic nerve proteins during 
regeneration of the goldfish retinotectal pathway. Brain Res 258:6978.

Reichardt LR, Tomaselli KJ (1991) Extracellular matrix molecules and their receptors: functions in the neural development. Annu Rev Neurosci 14:531-570.

Salles FJ, Schechter N, Strickland S (1990) A plasminogen activator is induced during goldfish optic nerve regeneration. EMBO J 9:24712477.

Schmidt JT, Schmidt R, Lin WC, Jian XY, Stuermer CA (1991) Ependymin as a substrate for outgrowth of axons from cultured explants of goldfish retina. J Neurobiol 22:40-54.

Schnell L, Schneider R, Kolbeck R, Barde Y-A, Schwab ME (1994) Neurotrophin-3 enhances sprouting of corticospinal tract during development and after adult spinal cord lesion. Nature 367:170-173.

Schwab ME, Caroni P (1988) Oligodendrocytes and CNS myelin are nonpermissive substrates for neurite growth and fibroblast spreading in vitro. J Neurosci 8:2381-2393.

Schwartz M, Agranoff BW (1981) Outgrowth and maintenance of neurites from cultured goldfish retinal ganglion cells. Brain Res 206:331 343.

Schwartz M, Belkin N, Harel A, Solomon A, Lavie V, Hadani M, Rachailovich I, Stein-Izsak C (1985) Regenerating fish optic nerves and regeneration-like responses in injured nerve of adult rabbits. Science 228:600-603.

Shashoua VE (1985) The role of extracellular proteins in neuroplasticity and learning. Cell Mol Neurobiol 5:183-207.

Sivron T, Schwab ME, Schwartz M (1994) Presence of growth inhibitors in fish optic nerve myelin: postinjury changes. J Comp Neurol $343: 237-246$.

Skene JHP, Willard M (1981a) Changes in axonally transported pro- teins during axon regeneration in toad retinal ganglion cells. J Cell Biol 89:86-95.

Skene JHP, Willard M (1981b) Axonally transported proteins associated with axon growth in rabhit central and peripheral nervous system. J Cell Biol 89:96-103.

Sperry RW (1944) Optic nerve regeneration with return of vision in anurans. J Neurophysiol 7:57 69.

Sperry RW (1963) Chemoaffinity in the orderly growth of nerve fiber patterns and connections. Proc Natl Acad Sci USA 50:703-710.

Thormodsson FR, Parker TS, Grafstein B (1992) Innmunochemical studies of extracellular glycoproteins (X-GPs) of goldfish brain. Exp Neurol 118:275-283.

Turner JE, Delaney RK, Johnson JE (1981) Retinal ganglion cell response to axotomy and nerve growth factor antiserum treatment in the regenerating visual system of the goldfish (Carassius auratus): an in vivo and in vitro analysis. Brain Res 204:283-294.

Turner JE, Schwab M, Thoenen H (1982) Nerve growth factor stimulates neurite outgrowth from goldfish retinal explants: the influence of a prior lesion. Dev Brain Res 4:59-66.

Vielmetter J, Lottspeich F, Stuemer CA (1991) The monoclonal antibody E587 recognizes growing (new and regenerating) retinal axons in the goldfish retinotectal pathway. J Neurosci 11:3581-3593.

Walicke PA, Varon S, Manthorpe M (1986) Purification of a human red blood cell protein supporting the survival of cultured CNS neurons, and its identification as catalase. J Neurosci 6:114-121.

Wilmot GR, Raymond PA, Agranoff BW (1993) The expression of the protein p68/70 within the gold-fish visual system suggests a role in both regeneration and neurogenesis. $J$ Neurosci 13:387-401.

Yip HK, Grafstein B (1982) Effect of nerve growth factor on regeneration of goldfish optic axons. Brain Res 238:329-339. 